\title{
$\stackrel{\rightleftharpoons}{\rightleftharpoons}$ \\ Bibliography
}

Albitte, Gustave and Dugard, Louis, Mon voisin d'omnibus, in La France dramatique au dix-neuvième siècle (Paris: Tresse, 1841).

Algazi Marcus, Lisa, 'The corruption of breastmilk in Alexandre Hepp's Le lait d'une autre', Romance Studies, 32:1 (2014), 3-15.

Alkan, Charles-Valentin, Les Omnibus. Variations dédiées aux Dames Blanches. Variation for piano in C major (Paris: M. Schlesinger, 1828).

Allen, James Smith, Popular French Romanticism: Authors, Readers, and Books in the 19th Century (Syracuse, NY: Syracuse University Press, 1981).

Almanach des Omnibus, des Dames blanches et autres voitures nouvellement établies (Paris: Lenormant fils, 1829).

Amann, Elizabeth, 'Reading (on) the tram: Benito Péres Galdós's "La novella en el tranvía”, Orbis Litterarium, 69:3 (2014), 193-214.

Amann, Elizabeth, 'The devil in the omnibus: from le Charivari to Blackwood's Magazine', Nineteenth-Century Contexts, 39:1 (2017), 1-13.

Aubryet, Xavier, 'La Chaussée d'Antin', in Paris-guide par les principaux écrivains et artistes de la France (Paris: Edition de la Découverte, 1983).

Auriac, Eugène d', Histoire anecdotique de l'industrie française (Paris: E. Dentu, 1861).

Baguley, David (ed.), 'La Curée' de Zola, ou 'la vie à outrance': Actes du colloque du 10 janvier 1987 (Paris: SEDES, 1987).

Balducci, Temma, Gender, Space, and the Gaze in Post-Haussmann Visual Culture (New York: Routledge, 2017).

Balducci, Temma and Jensen, Heather Belnap (eds), Women, Femininity and Public Space in European Visual Culture, 1789-1914 (Farnham: Ashgate, 2014).

Balzac, Honoré de, Histoire et physiologie des Boulevards de Paris. De la Madeleine à la Bastille', in Le Diable à Paris, 2 vols (Paris: Hetzel, 1845-46, II (1846)).

Balzac, Honoré de, La Comédie humaine, vol. 5 (Paris: Gallimard, 1977).

Balzac, Honoré de, Ferragus, in Histoire des treize (Paris: Garnier-Flammarion, 1988).

Bastard, George, Paris qui roule (Paris: Georges Chamerot, 1889).

Baudelaire, Charles, Euvres complètes (Paris: Gallimard, 1938).

Baudelaire, Charles, The Parisian Prowler, trans. Edward Kaplan (Athens, GA: University of Georgia Press, 1989). 


\section{Engine of modernity}

Beaumont, Matthew and Freeman, Michael (eds), The Railway and Modernity. Time, Space, and the Machine Ensemble (Oxford: Peter Lang, 2007).

Belenky, Masha, 'From transit to transitoire: omnibus and modernity', NineteenthCentury French Studies, 35:1/2 (2007), 84-96.

Belenky, Masha, 'Transitory tales: writing the omnibus in nineteenth-century Paris', Dix-Neuf: Journal of the Society of Dix-Neuviemistes, 16:3 (2012), https://www. tandfonline.com/doi/full/10.1179/1478731811Z.0000000005.

Belenky, Masha, 'Disordered topographies in Zola's La Curée', Romance Notes 53:1 (2013), 27-36.

Bell, David, Real Time: Accelerating Narrative from Balzac to Zola (Chicago, IL: University of Illinois Press, 2004).

Bellu, René, Les Autobus parisiens des origines à nos jours (Paris: Delville, 1979).

Benjamin, Walter, The Arcades Project, trans. Howard Eiland and Kevin McLaughlin (Cambridge, MA: Harvard University Press, 1999).

Berman, Marshall, All That Is Solid Melts into Air: The Experience of Modernity (New York: Penguin, 1988).

Bernard, Léo de, 'Les Wagons de Paris', Naguère et Jadis (March 1964).

Bernheimer, Charles, Figures of Ill Repute: Representing Prostitution in NineteenthCentury France (Durham, NC: Duke University Press, 1997).

Boisgobey, Fortuné de, Le Crime de l'omnibus (Paris: Encage, 2005).

Boutin, Aimée (ed.), 'The flâneur and the senses', Dix-Neuf: Journal of the Society of Dix-Neuvièmistes, 16:2 (2012).

Boutin, Aimée, City of Noise: Sound and Nineteenth-Century Paris (Urbana, IL: University of Illinois Press, 2015).

Bowie, Karen (ed.), La Modernité avant Haussmann: formes de l'espace urbain à Paris 1801-1853 (Paris: Editions Recherches, 2000).

Byle-Mouillard, Elisabeth Félicie, Manuel complet de la bonne companie or guide de la politesse, des égards, du bon ton et de la bienséance, 5th edn (Paris: F. Ancelle, 1829).

Calmettes, Pierre, 'En Omnibus', Le Monde Moderne (1906), 242-6.

Carter, Ian, Railways and Culture in Britain: The Epitome of Modernity (Manchester: Manchester University Press, 2001).

Certeau, Michel de, The Practice of Everyday Life, trans. Steven Rendall (Berkeley, CA: University of California Press, 1984).

Chalogne, Florence de, 'Espaces, regards et perspectives: la promenade au Bois de Boulogne dans La Curée d'Emile Zola', Littérature, 65 (1987), 58-69.

Charles, David, 'Le trognon et l'omnibus: faire de sa misère sa barricade', in Alain Corbin and Jean-Marie Mayeur (eds), La Barricade (Paris: Publications de la Sorbonne, 1997).

Childs, Elizabeth C., Daumier and Exoticism: Satirizing the French and the Foreign (New York: Peter Lang, 2004).

Clarétie, Jules, 'Les omnibus parisiens', Les annales politiques et littéraires, 1200 (24 June 1906).

Clayson, Hollis, Painted Love: Prostitution in French Art of the Impressionist Era (New Haven, CT: Yale University Press, 1991).

Cohen, Margaret, 'Panoramic literature and the invention of everyday genres', in Leo Charney and Vanessa Schwartz (eds), Cinema and the Invention of Modern Life (Berkeley, CA: University of California Press, 1996). 


\section{Bibliography}

Cohen, Richard I., 'The "Wandering Jew” from medieval legend to modern metaphor', in Barbara Kirshenblatt-Gimblett and Jonathan Karp (eds), The Art of Being Jewish in Modern Times (Philadelphia, PA: University of Pennsylvania Press, 2008).

Colette, Claudine à l'école (Paris: Albin Michel, 1976).

Coppée, François, 'Croquis parisiens: l'omnibus', Les annales politiques et littéraires (7 September 1902).

Coppée, François, 'Physionomies parisiennes: le conducteur de l'omnibus', Les annales politiques et littéraires, 1200 (24 June 1906).

Corbin, Alain, Women for Hire: Prostitution and Sexuality in France after 1850, trans. Alan Sheridan (Cambridge, MA: Harvard University Press, 1996).

Darasse, P., 'Un coup de foudre en omnibus', Comédies pour salons et théâtre, 2nd edn (Paris: impr. de la Publicité générale, 1889).

Dartès, Emile, Contes en omnibus (Paris: Flammarion, 1894).

Davidson, Denise, France after the Revolution: Urban Life, Gender, and the New Social Order (Cambridge, MA: Harvard University Press, 2007).

Dejean, Joan, How Paris Became Paris: The Invention of the Modern City (New York and London: Bloomsbury, 2014).

Delord, Taxile, Arnould Frémy and Edmond Texier, Paris-en-omnibus (Paris: Libraire d'Alphonse Taride, 1854).

D'Souza, Aruna and McDonough, Tom (eds), The Invisible Flâneuse? Gender, Public Space, and Visual Culture in Nineteenth-Century Paris (Manchester: Manchester University Press, 2006).

Du Camp, Maxime, 'Les voitures publiques dans la ville de Paris: les Fiacres et les Omnibus', Revue de deux mondes, 62 (1867), 318-52.

Du Camp, Maxime, Paris, ses organes, ses fonctions et sa vie dans la seconde moitié $d u$ XIXe siècle, 6 vols (Paris: Hachette, 1869-75).

Ducoux, 'Les voitures publiques de Paris', Paris-guide par les principaux écrivains et artistes de la France, vol. 2 (Paris: A. Lacroix et Verboeckhoven, 1867).

Dufay, Pierre, 'Le Triomphe et le bicentenaire des omnibus', Mercure de France (1 February 1928), 628-40.

Duffy, Larry, Le Grand Transit Moderne: Mobility, Modernity, and French Naturalist Fiction (Amsterdam: Rodopi, 2005).

Dupeuty, Charles, De Courcy, Frédéric and Lassagne, Espérance, Les omnibus, ou la revue en voiture (Paris: J.-N. Barba, 1828).

Faÿ-Sallois, Fanny, Les Nourrices à Paris au XIXe siècle (Paris: Payot, 1980).

Felski, Rita, The Gender of Modernity (Cambridge, MA: Harvard University Press, 1995). Ferguson, Priscilla Parkhurst, 'The flâneur on and off the streets of Paris', in Keith Tester (ed.), The Flâneur (London: Routledge, 1994).

Ferguson, Priscilla Parkhurst, Paris as Revolution: Writing the Nineteenth-Century City (Berkeley, CA: University of California Press, 1994).

Flaubert, Gustave, Correspondance, 1856 (Paris: L. Conard, 1926-54).

Flaubert, Gustave, L'éducation sentimentale (Paris: Les Belles Lettres, 1942).

Flaubert, Gustave, Madame Bovary (Paris: Gallimard, 2004).

Flesselles, Comptesse de, Les jeunes voyageurs dans Paris (Paris: Locard et Davi, 1829).

Forbes, Amy Wiese, The Satiric Decade: Satire and the Rise of Republicanism in France, 1830-1840 (Lanham, MD: Lexington Books, 2010). 


\section{Engine of modernity}

Fouinet, Ernest, 'Un voyage en omnibus de la barrière du Thrône à la barrière de l'Etiole', in Paris, ou le livre des cent-et-un, vol. 2 (Paris: C. Ladvocat, 1831).

Fournel, Victor, Ce quion voit dans les rues de Paris (Paris: Delahays, 1858).

Fournier, Edouard, Paris démoli (Paris: E. Dentu, 1883).

Friès, Charles, 'Le Conducteur d'omnibus', in Les Français peints par eux-mêmes: encyclopédie morale du dix-neuvième siècle (Paris: Curmer, 1840-42).

Fuchs, Rachel G. and Thompson, Victoria E, Women in Nineteenth-Century Europe (New York: Palgrave, 2005).

Gabriel, J. and Vermond, P., J'attends un omnibus (Bruxelles: J-A Lelong, 1849).

Gaillard, Marc, Histoire des transports parisiens: de Blaise Pascal à nos jours (Le Coteau: Horvath, 1987).

Gaillard, Marc, Du Madeleine-Bastille à Météor: histoire des transports parisiens (Amiens: Martelle, 1991).

Gautier, Théophile, Dumas, Alexandre and de Musset, Paul, Paris et les Parisiens au XIXe siècle (Paris: Morizot, 1856).

Gavarni, Paul, 'Une aventure d'omnibus', Le Charivari (26 August 1840).

Gavin, A. and Humphries, A. (eds), Transport in British Fiction: Technologies of Movement, 1840-1940 (London: Palgrave, 2015).

Girardin, Delphine de, Chroniques parisiennes, Jean-Louis Vissière (ed.) (Paris: Des femmes, 1986).

Gluck, Mary, Popular Bohemia: Modernism and Urban Culture in Nineteenth-Century Paris (Cambridge, MA: Harvard University Press, 2008).

Goncourt, Edmond de and Goncourt, Jules de, Journal, 1 (1851-63), A. Ricatte (ed.) (Paris: Flammarion, 1959).

Gourdon, Edouard, Physiologie de l'omnibus (Paris: Terry, 1842).

Gozlan, Léon, Le Triomphe des Omnibus (Paris: Abroise Dupont, 1828).

Green, Anne, Changing France: Literature and Material Culture in the Second Empire (London: Anthem Press, 2011).

Griveau, Lucien, 'En omnibus', Journal des démoiselles, 51:2 (1883), 48-50.

Guerrand, Roger-Henri, Mœurs citadines. Histoire de la culture urbaine, XIX-XXe siècles (Paris: Edima, 1992).

Hahn, H. Hazel, Scenes of Parisian Modernity: Culture and Consumption in NineteenthCentury Paris (New York: Palgrave Macmillan, 2009).

Harrow, Susan, Emile Zola, La Curée (Glasgow: University of Glasgow French and German Publications, 1998).

Harvey, David, Paris, Capital of Modernity (New York: Routledge, 2003).

Hénard, Robert, 'En omnibus', Le Magasin Pittoresque (January 1898), 346-9.

Higonnet, Patrice, Paris: Capital of the World (Cambridge, MA: Harvard University Press, 2002).

Hiner, Susan, Accessories to Modernity: Fashion and the Feminine in Nineteenth-Century France (Philadelphia, PA: University of Pennsylvania Press, 2010).

Huart, Louis, 'Les voitures publiques', in Nouveau tableau de Paris au XIXe siècle, vol. 4 (Paris: Madame Charles-Béchet, 1834).

Huart, Louis, Physiologie du flaneur (Paris: Aubert, 1841).

Hugo, Victor, Les Misérables (Paris: Garnier, 1963). 


\section{Bibliography}

Janin, Jules, L'omnibus complet (Paris: J. Juteau, 1866).

Kalifa, Dominique, La Culture en masse en France, 1860-1930 (Paris: La Découverte, 2001).

Kalifa, Dominique (ed.), La Civilisation du journal. L'histoire culturelle et littéraire de la presse au XIXe siècle (Paris: Nouveau Monde, 2011).

Kessler, Marni, Sheer Presence: The Veil in Manet's Paris (Minneapolis, MN: University of Minnesota Press, 2006).

Kock, Paul de, 'Etudes de mœurs. Les pensionnats à voiture', Musée des familles (1 January 1841).

Lasserre, Paris en omnibus, itinéraire pittoresque, historique et industriel. Ligne $H$, de l'Odéon à Clichy (Paris: A. Parent, 1867).

Lauster, Martina, Sketches of the Nineteenth Century: European Journalism and Its Physiologies, 1830-50 (Basingstoke: Palgrave Macmillan, 2007).

Lavollée, Charles, Les Omnibus à Paris et à Londres (Paris: Renou \& Maulde, 1868).

Levy, Amy, 'Ballad of an omnibus', Representative Poetry Online, https://rpo.library. utoronto.ca/poems/ballade-omnibus, accessed 24 September 2018.

Loeillot, Karl, Les Nouvelles voitures publiques de Paris (Paris: Gihaut Frères, 1832).

Lyon-Caen, Judith, 'Saisir, décrire, déchiffrer: les mises en texte du social sous la monarchie de Juillet', Revue Historique, 306:2 (2004), 301-30.

Lyons, Martyn, A History of Reading and Writing in the Western World (New York: Palgrave, 2010).

Mainardi, Patricia, Husbands, Wives, and Lovers: Marriage and Its Discontents in Nineteenth-Century France (New Haven, CT: Yale University Press, 2003).

Mainardi, Patricia, Another World: Nineteenth-Century Illustrated Print Culture (New Haven, CT: Yale University Press, 2017).

Marcus, Sharon, Apartment Stories: City and Home in Nineteenth-Century Paris and London (Berkeley, CA: University of California Press, 1999).

Marcus, Sharon, 'Transparence de l'appartement parisien entre 1820 et 1848', in Karen Bowie (ed.), La Modernité avant Haussmann: formes de l'espace urbain à Paris 1801-1853 (Paris: Editions Recherches, 2000).

Martin-Fugier, Anne, La Vie élégante, ou, la formation de Tout-Paris 1815-1848 (Paris: Fayard, 1990).

Matlock, Jann, Scenes of Seduction: Prostitution, Hysteria, and Reading Difference in Nineteenth-Century France (New York: Columbia University Press, 1994).

Matthews David, Alison, Fashion Victims: The Dangers of Dress Past and Present (New York: Bloomsbury, 2015).

Maupassant, Guy de, 'Le père Mongilet', Gil Blas (24 February 1885).

Maupassant, Guy de, Contes et Nouvelles, Albert-Marie Schmidt and Gérard Delaisement (eds) (Paris: Albin Michel, 1957).

Maupassant, Guy de, Contes et Nouvelles, Louis Forestier (ed.) (Paris: Gallimard, 1974).

Maza, Sarah, The Myth of the French Bourgeoisie (Cambridge, MA: Harvard University Press, 2003).

Meiner, Carsten, Le carrosse littéraire et l'invention du hasard (Paris: Presses Universitaires de France, 2008).

Mowll Mathews, Nancy, and Shapiro, Barbara Stern, Mary Cassatt: The Color Prints (New York: Harry N. Abrams, 1989). 


\section{Engine of modernity}

Nead, Lynda, The Victorian Babylon: People, Streets and Images in Nineteenth-Century London (New Haven, CT: Yale University Press, 2000).

Nead, Lynda, 'The layering of pleasure: fashionable dress and visual culture in the mid-nineteenth century', Nineteenth-Century Contexts: An Interdisciplinary Journal, 35:5 (2013).

Nelson, Brian, Zola and the Bourgeoisie: A Study of Themes and Techniques in Les Rougon-Macquart (London: Macmillan, 1983).

Nesci, Catherine, Le fâneur et les flâneuses. Les femmes et la ville à l'époque romantique (Grenoble: Ellug, 2007).

Nogaret, Félix, Réflexions d'un patriarche sur les voitures dites omnibus! (Paris: Leclerc, 1828).

Les omnibus. Premier voyage de Cadet la Blague de la place de la Madeleine à la Bastille et retour (Paris: Chez Chassaignon, 1828).

O'Neil-Henry, Anne, Mastering the Marketplace: Popular Literature in NineteenthCentury France (Lincoln, NE: University of Nebraska Press, 2017).

Papayanis, Nicholas, Horse-Drawn Cabs and Omnibuses in Paris: The Idea of Circulation and the Business of Public Transit (Baton Rouge, LA: Louisiana State University Press, 1996).

Papayanis, Nicholas, Paris before Haussmann (Baltimore, MD and London: Johns Hopkins University Press, 2004).

Paris en omnibus. Guide familier dans le Paris de 1869 (Paris Ancien et Paris Nouveau) par un simple voyageur en omnibus, en chemin de ceinture et en bateau mouche indiquant les rencontres et les correspondances de ces divers modes de locomotion dans Paris (Paris: Chez les principaux libraires et dans tous les bureaux d'omnibus, 1869).

Pinkney, David H., Napoleon III and the Rebuilding of Paris (Princeton, NJ: Princeton University Press, 1958).

Pinkney, David H., Decisive Years in France 1840-1847 (Princeton, NJ: Princeton University Press, 1986).

Pollock, Griselda, Vision and Difference: Femininity, Feminism and the Histories of Art (London: Routledge, 1988).

Pollock, Griselda, Mary Cassatt: Painter of Modern Women (London: Thames and Hudson, 1998).

Preiss, Nathalie, Les Physiologies en France au XIXe siècle (Mont-de-Marsan: Editions Inter-Universitaires, 1999).

Prendergast, Christopher, Paris and the Nineteenth-Century (Oxford: Blackwell, 1995).

'Quelques remarques sur les omnibus', Le Magasin pittoresque (1843).

Raymond, Emmeline, 'L'Omnibus', La Mode Illustrée (27 October 1862), 351-2.

Renoy, Georges, Paris au temps des omnibus (Bruxelles: Rossel Edition, 1976).

Reverzy, Eléonore, Portrait de l'artiste en fille de joie. La Littérature publique (Paris: CNRS Édition, 2016).

Rice, Shelley, Parisian Views (Cambridge, MA: MIT Press, 1997).

Rich, Rachel, Bourgeois Consumption: Food, Space and Identity in London and Paris, 1850-1914 (Manchester: Manchester University Press, 2011).

Riffaterre, Michael, 'Flaubert's presuppositions', in Naomi Schor and Henry F. Majewski (eds), Flaubert and Postmodernism (Lincoln, NE: University of Nebraska Press, 1984). 


\section{Bibliography}

Roubaud, Jacques, Ode à la ligne 29 des autobus parisiens (Paris: Attila, 2013).

Sand, George and Sandeau, Jules, 'Le Commissionnaire', George Sand: Euvres complètes 1829-1831: George Sand avant 'Indiana', 2 vols, Yves Chastagnaret (ed.) (Paris: Honoré Champion, 2008).

Schivelbusch, Wolfgang, The Railway Journey: The Industrialization of Time and Space in the Nineteenth Century (Berkeley, CA: University of California Press, 1986).

Schwartz, Vanessa, Spectacular Realities: Early Mass Culture in Fin-de-siècle Paris (Berkeley, CA: University of California Press, 1998).

Sennett, Richard, Flesh and Stone: The Body and the City in Western Civilization (New York: Norton, 1994).

Sieburth, Richard, 'Same difference: the French Physiologies, 1840-1842', in Norman F. Cantor (ed.), Notebooks in Cultural Analysis: An Annual Review (Durham, NC: Duke University Press, 1984).

Siegel, François, Les Archives inédites de la RATP (Neuilly-sur-Seine: Lafon, 2011).

Silverman, Willa, The New Bibliopolis, French Book Collectors and the Culture of Print, 1880-1914 (Toronto: University of Toronto Press, 2008).

Simmel, Georg, 'The metropolis and mental life', in Gary Bridge and Sophie Watson (eds), The Blackwell City Reader (Malden: Blackwell, 2002).

Soppelsa, Peter, 'The instrumentalisation of horses in nineteenth-century Paris', in Rob Boddice (ed.), Anthropocentrism: Humans, Animals, Environments (Leiden and Boston: Brill, 2011).

Soppelsa, Peter, 'The end of horse transportation in Belle-Époque Paris', Interdisciplinary Studies in Literature and Environment, 24:1 (2017), 113-29.

Soullier, Charles, Les omnibus de Paris, pièce curieuse et utile à l'usage des voyageurs dans Paris, contenant une liste alphabétique des 31 omnibus, avec leurs parcours, etc., accompagnée de notes historiques et statistiques très intéressantes et d'un indicateur général des monuments, musées, etc. (Paris: Cordier, 1863).

Spang, Rebecca L., The Invention of the Restaurant: Paris and Modern Gastronomic Culture (Cambridge, MA: Harvard University Press, 2001).

Stiénon, Valérie, 'La vie littéraire par le kaléidoscope des Physiologies', in La Vie littéraire et artistique aux XIXe siècle (2011).

Stiénon, Valérie, 'Le canon littéraire au crible des physiologies', Revue d'Histoire Littéraire de la France, 114:1 (2014), 131-41.

Stierle, Karlheinz, La Capitale des signes: Paris et son discours (Paris: La Maison des Sciences des Hommes, 2001).

Studeny, Christophe, L'Invention de la vitesse (Paris: Gallimard, 1995).

Sussman, George D., 'The wet nurse in Daumier's Third-Class Carriage', Metropolitan Museum Journal, 53 (2018), 83-95.

Tanner, Jessica, 'Speculative Paris: Zola's repossession of Paris', L'Esprit Créateur, 55:3 (2015), 114-26.

Terdiman, Richard, Discourse/Counter-Discourse. The Theory and Practice of Symbolic Resistance in Nineteenth-Century France (Ithaca, NY: Cornell University Press, 1985).

Terni, Jennifer, 'A genre for early mass culture: French vaudeville and the city, 1830-48', Theater Journal, 58:2 (2006), 221-8.

Terni, Jennifer, 'The omnibus and the shaping of the urban quotidian', Cultural and Social History, 11:2 (2015), 217-42. 


\section{Engine of modernity}

Tester, Keith (ed.), The Flâneur (London: Routledge, 1994).

Texier, Edmond, 'Les voitures à Paris', Tableau de Paris, vol. 2 (Paris: Paulin et le Chevalier, 1852-53).

Thérenty, Marie-Eve, Mosaïque: être écrivain entre presse et roman (1829-1836) (Paris: Éditions Honoré Champion, 2003).

Thérenty, Marie-Eve and Vaillant, Alain (eds), La Presse au XIXe siècle: les modes de diffusions d'une industrie culturelle (Paris: Nouveau Monde, 2004).

Thomas, Greg, 'Women in public in the parks of Paris', in Aruna D'Souza and Tom McDonough (eds), The Invisible Flâneuse? Gender, Public Space, and Visual Culture in Nineteenth-Century Paris (Manchester: Manchester University Press, 2006).

Thompson, Victoria, The Virtuous Marketplace: Women and Men, Money and Politics in Paris, 1830-1870 (Baltimore, MD: Johns Hopkins University Press, 2000).

Thompson, Victoria, 'Telling "spatial stories": urban space and bourgeois identities in early nineteenth-century Paris', Journal of Modern History, 75:3 (2003), 523-56.

Uzanne, Octave, La Locomotion à travers le temps, les mours et l'espace. Résumé pittoresque et anecdotique de l'histoire générale des moyens de transports terrestres et aériens (Paris: Librairies Paul Ollendorf, 1900).

Uzanne, Octave, 'Omnibus de Paris', Le Monde Moderne, 1.28 (1900), 481-94.

Vadillo, Ana Pareja, 'Phenomena in flux: the aesthetics and politics of travelling in modernity', in Ann L. Ardis and Leslie W. Lewis (eds), Women's Experience of Modernity 1875-1945 (Baltimore: Johns Hopkins University Press, 2003).

Van Zanten, David, Building Paris: Architectural Institutions and the Transformation of the French Capital, 1830-1870 (Cambridge: Cambridge University Press, 1994).

Walkowitz, Judith, City of Dreadful Delight: Narratives of Sexual Danger in Late Victorian London (Chicago, IL: University of Chicago Press, 1992).

Wechsler, Judith, A Human Comedy: Physiognomy and Caricature in NineteenthCentury Paris (Chicago, IL: University of Chicago Press, 1982).

Wilson, Elizabeth, The Sphinx in the City: Urban Life, the Control of Disorder, and Women (Berkeley, CA: University of California Press, 1991).

Wilson, Elizabeth, 'The invisible flâneur', New Left Review, I.191 (1994), 90-110.

Wolff, Janet, 'The invisible flâneuse: women and the literature of modernity', Theory, Culture, and Society, 2:3 (1985), 37-46.

Zola, Emile, La Curée (Paris: Gallimard, 1981).

Zola, Emile, Au Bonheur des Dames (Paris: Flammarion, 1999).

Zola, Emile, The Kill, trans. Brian Nelson (Oxford: Oxford Univercity Press, 2004).

Zuber, Henri, Hallsted-Baumert, Sheila and Berton, Claude, Guide des sources de l'bistoire des transports publics urbains à Paris et en Ile-de-France, XIXe-XXe siècles (Paris: Publications de la Sorbonne, 1998). 